Polyovyy V., Dzyubanovsky I., Kovalchuk A., Dzyubanovsky O., Dzhyvak V. Dynamics of cytokine profile in patients with abdominal sepsis caused by pancreonecrosis. Journal of Education, Health and Sport. 2021;11(05): 207-212. eISSN 2391-8306. DOI http://dx.doi.org/10.12775/JEHS.2021.11.05.021

https://apcz.umk.pl/czasopisma/index.php/JEHS/article/view/JEHS.2021.11.05.021

https://zenodo.org/record/5035539

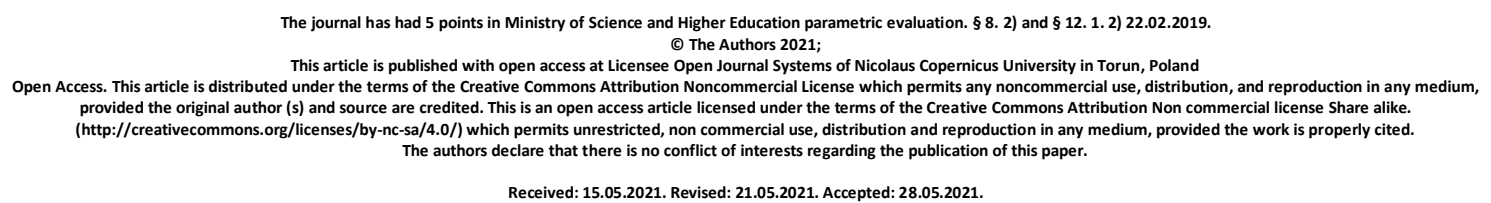

\title{
DYNAMICS OF CYTOKINE PROFILE IN PATIENTS WITH ABDOMINAL SEPSIS CAUSED BY PANCREONECROSIS
}

\author{
V. P. Polyovyy' ${ }^{\text {, I. Ya. Dzyubanovsky }}{ }^{2}$, A. A. Kovalchuk² , O. I. Dzyubanovsky², \\ V. H. Dzhyvak ${ }^{2}$ \\ ${ }^{1}$ Bukovinian State Medical University \\ ${ }^{2}$ I. Horbachevsky Ternopil National Medical University
}

Polyovyy V. P. http://orcid.org/0000-0002-4345-9802

Dzyubanovsky I. Ya. http://orcid.org/0000-0001-8852-3938

Kovalchuk A. A. https://orcid.org/0000-0003-1394-7546

Dzyubanovsky O. I. https://orcid.org/0000-0003-4343-2797

Dzhyvak V. H. https://orcid.org/0000-0002-4885-75861

\section{Abstract}

Acute pancreatitis is one of the most pressing problems of modern pancreatology, according to the authors ranks first among surgical pathologies.

The aim of this study was to evaluate the dynamics of cytokine profile in patients with abdominal sepsis caused by pancreatic necrosis.

\section{Materials and methods.}

The study was conducted in 12 patients diagnosed with abdominal sepsis caused by pancreatic necrosis, in the period from 2017 to 2020 who were treated in medical hospitals in Chernivtsi and Ternopil. The control group consisted of 17 patients without signs of abdominal sepsis and acute surgical pathology. Both groups were representative by age, sex, comorbidities, risk factors. Determination of experimental parameters in the blood of patients 
was performed in the postoperative period (the results were evaluated before surgery, on the first and tenth days of the postoperative period).

\section{Research results and their discussion.}

In patients with abdominal sepsis, a violation of the mechanisms of cell adhesion and costimulatory-cooperative interaction of immunocompetent cells was observed in the preoperative period, as indicated by the low level of CD11a + and CD162 + expression on them. The decrease in the content of IL-6 in the blood with a slight progressive increase in the level of IL-4 corresponds to a moderate imbalance of cytokine regulation of the immune response.

\section{Key words: sepsis; cytokines; pancreatic necrosis.}

\section{Introduction.}

Acute pancreatitis is one of the most pressing problems of modern pancreatology, according to the authors ranks first among surgical pathologies. Infected pancreatic necrosis develops in $30-70 \%$ of patients with severe acute pancreatitis and is a major risk factor for death $[1,2]$. Acute pancreatitis is a dynamic process with various pathophysiological mechanisms of focal and systemic complications [3]. To prevent systemic inflammation, mechanisms that control the production of anti-inflammatory cytokines and their inhibitors are involved $[4,5]$. Pancreatic necrosis is a pathological process characterized by the death of organ tissue under the influence of damaging factors. One of the leading causes of death in patients with pancreatic necrosis is sepsis. According to various authors, in infected forms of pancreatic necrosis, abdominal sepsis develops in 15-47\% of cases. In turn, the lethal outcome in patients with pancreatogenic sepsis is observed according to different data in $15-80 \%$ of cases $[6,7]$.

Abdominal sepsis is one of the current problems of modern surgery, which is intensively studied by both domestic and foreign researchers [8,9]. The term abdominal sepsis is a pathology characterized by the development of systemic inflammatory reaction syndrome in primary and secondary infectious processes in the abdominal cavity or retroperitoneal space $[10,11]$. This explains the high mortality rate among such patients, which is more than $10 \%$ at the initial stage of the disease [12].

In response to stress, the body regulates the cytokine profile, which indicates the important role of endocrine effects on the body's immune response and the development of immune dysregulation during stress. Cytokines regulate neurotransmission and also induce hormonal changes similar to those caused by stress. Despite the existing scientific research 
aimed at studying and assessing the cytokine status in the pathology of abdominal sepsis, the immune component is insufficiently studied $[13,14,15]$.

The aim of the work was to evaluate the dynamics of cytokine profile in patients with abdominal sepsis caused by pancreatic necrosis.

\section{Materials and methods}

The study was conducted in 12 patients diagnosed with abdominal sepsis caused by pancreatic necrosis, in the period from 2017-2020 who were treated in medical institutions of Chernivtsi and Ternopil. The control group consisted of 17 patients without signs of abdominal sepsis and acute surgical pathology. Both groups were representative by age, sex, comorbidities, risk factors. Determination of experimental parameters in the blood of patients was performed in the postoperative period (the results were evaluated before surgery, on the first and tenth days of the postoperative period).

\section{Research results and their discussion}

In patients with abdominal sepsis caused by pancreatic necrosis (Table 1), the initial level of CD11a + cells, CD162 + -positive cells and CD95 + lymphocytes is twice less than the control. On the first day after surgery, the relative number of immunocompetent cells was further reduced, resulting in the level of CD11a + cells 2.6 times ( $p<0.001)$, CD162 + cells 1.6 times $(\mathrm{p}<0.01)$, CD95 + lymphocytes are 2.5 ( $\mathrm{p}<0.001)$ times lower than in healthy individuals.

On the tenth day of the postoperative period, the content of CD11a + cells in the blood increased 1.66 times $(\mathrm{p}<0.001)$ and remained lower than the control values by 1.2 times $(\mathrm{p}$ $<0.05)$. The level of CD95 + lymphocytes increased 1.6 times $(\mathrm{p}<0.001)$, but remained 1.3 times ( $\mathrm{p}<0.05)$ less than the control. The content of CD16 + leukocytes in the blood also increased 1.5 times $(\mathrm{p}<0.05)$ and exceeded the control $(\mathrm{p}<0.01)$.

Thus, before surgery, there is a violation of the mechanisms of cellular immunity, namely a decrease in the level of expression of CD11a + and CD162 +.

In addition, the mechanisms of lymphocyte activation suffer - the content of CD95 + cells in the blood is twice lower than in almost healthy individuals. Surgical intervention contributes to a very effective correction of these changes and increases the level of CD16 + leukocytes in the blood (Table 2). 
Table 1. Peculiarities of expression of determination clusters on immunocompetent cells of patients with abdominal sepsis caused by pancreatic necrosis $(\mathrm{x} \pm \mathrm{Sx})$

\begin{tabular}{|l|l|l|l|l|}
\hline Groups of patients & $\begin{array}{l}\text { CD11a } \\
(\%)\end{array}$ & $\begin{array}{l}\text { CD162 } \\
(\%)\end{array}$ & $\begin{array}{l}\text { CD95 } \\
(\%)\end{array}$ & $\begin{array}{l}\text { CD16 } \\
(\%)\end{array}$ \\
\hline $\begin{array}{l}\text { Control, } \\
(\mathrm{n}=17)\end{array}$ & $63,12 \pm 2,49$ & $58,67 \pm 3,05$ & $19,45 \pm 1,02$ & $23,64 \pm 1,45$ \\
\hline $\begin{array}{l}\text { Initial level, } \\
(\mathrm{n}=12)\end{array}$ & $\begin{array}{l}32,64 \pm 1,96 \\
\mathrm{p}<0,001\end{array}$ & $\begin{array}{l}28,76 \pm 1,68 \\
\mathrm{p}<0,001\end{array}$ & $\begin{array}{l}8,12 \pm 0,63 \\
\mathrm{p}<0,001\end{array}$ & $\begin{array}{l}19,27 \pm 1,96 \\
\mathrm{p}>0,6\end{array}$ \\
\hline $\begin{array}{l}\text { The 1-st day after } \\
\text { surgery, } \\
(\mathrm{n}=12)\end{array}$ & $\begin{array}{l}23,78 \pm 1,17 \\
\mathrm{p}<0,001 \\
\mathrm{p} 1<0,01\end{array}$ & $\begin{array}{l}36,75 \pm 2,31 \\
\mathrm{p}<0,001 \\
\mathrm{p} 1<0,05\end{array}$ & $\begin{array}{l}7,12 \pm 0,38 \\
\mathrm{p}<0,001 \\
\mathrm{p} 1>0,05\end{array}$ & $\begin{array}{l}24,48 \pm 2,14 \\
\mathrm{p}>0,1 \\
\mathrm{p} 1>0,1\end{array}$ \\
\hline $\begin{array}{l}\text { The 10-th day after } \\
\text { surgery, } \\
(\mathrm{n}=12)\end{array}$ & $\begin{array}{l}52,93 \pm 3,23 \\
\mathrm{p}<0,05 \\
\mathrm{p} 1<0,001 \\
\mathrm{p} 2<0,001\end{array}$ & $\begin{array}{l}48,56 \pm 2,73 \\
\mathrm{p}>0,08 \\
\mathrm{p} 1<0,001 \\
\mathrm{p} 2<0,02\end{array}$ & $\begin{array}{l}13,48 \pm 1,22 \\
\mathrm{p}<0,05 \\
\mathrm{p} 1<0,01 \\
\mathrm{p} 2<0,001\end{array}$ & $\begin{array}{l}31,12 \pm 3,24 \\
\mathrm{p}<0,01 \\
\mathrm{p} 1<0,05 \\
\mathrm{p} 2>0,2\end{array}$ \\
\hline
\end{tabular}

Table 2. The level of HLA-DR + molecules and the content of cytokines in the blood of patients with abdominal sepsis caused by pancreatic necrosis $(x \pm S x)$

\begin{tabular}{|c|c|c|c|c|}
\hline Groups of patients & $\begin{array}{l}\text { HLA-DR+ } \\
(\%)\end{array}$ & $\begin{array}{l}\text { IL-2 } \\
(\mathrm{pg} / \mathrm{ml})\end{array}$ & $\begin{array}{l}\text { IL-4 } \\
(\mathrm{pg} / \mathrm{ml})\end{array}$ & $\begin{array}{l}\text { IL-6 } \\
(\mathrm{pg} / \mathrm{ml})\end{array}$ \\
\hline $\begin{array}{l}\text { Control, } \\
(\mathrm{n}=17)\end{array}$ & $16,13 \pm 0,83$ & $214,78 \pm 10,11$ & $223,01 \pm 11,53$ & $220,18 \pm 9,89$ \\
\hline $\begin{array}{l}\text { Initial level, } \\
(n=12)\end{array}$ & $\begin{array}{l}16,98 \pm 1,54 \\
p>0,7\end{array}$ & $\begin{array}{l}222,56 \pm 13,67 \\
p>0,8\end{array}$ & $\begin{array}{l}295,22 \pm 17,34 \\
p<0,01\end{array}$ & $\begin{array}{l}171,52 \pm 8,44 \\
p<0,02\end{array}$ \\
\hline $\begin{array}{l}\text { The 1-st day after } \\
\text { surgery, } \\
(n=12)\end{array}$ & $\begin{array}{l}16,89 \pm 1,23 \\
p>0,7 \\
p 1>0,5\end{array}$ & $\begin{array}{l}209,48 \pm 10,18 \\
p>0,6 \\
p 1>0,4\end{array}$ & $\begin{array}{l}333,86 \pm 18,12 \\
p<0,001 \\
p 1>0,1\end{array}$ & $\begin{array}{l}133,12 \pm 8,11 \\
p<0,001 \\
p 1<0,01\end{array}$ \\
\hline $\begin{array}{l}\text { The 10-th day after } \\
\text { surgery, } \\
(n=12)\end{array}$ & $\begin{array}{l}16,83 \pm 1,64 \\
\text { p }>0,6 \\
\text { p1>0,5 } \\
\text { p2>0,9 }\end{array}$ & $\begin{array}{l}219,43 \pm 9,87 \\
\text { p }>0,9 \\
\text { p1 }>0,8 \\
\text { p2 }>0,4\end{array}$ & $\begin{array}{l}397,32 \pm 19,83 \\
\text { p }<0,001 \\
\text { p } 1<0,01 \\
\text { p2 }<0,01\end{array}$ & $\begin{array}{l}97,37 \pm 4,25 \\
\text { p }<0,001 \\
\text { p1<0,001 } \\
\text { p2<0,01 }\end{array}$ \\
\hline \multicolumn{5}{|c|}{$\begin{array}{l}\text { Notes: } \\
\mathrm{p} \text { - the degree of probability of differences in indicators relative to control; } \mathrm{p} 1 \text { - the } \\
\text { degree of probability of differences in indicators relative to the initial level; } \mathrm{p} 2 \text { - the degree } \\
\text { of probability of differences relative to the data on the first day after surgery; } \mathrm{n} \text { is the } \\
\text { number of observations. }\end{array}$} \\
\hline
\end{tabular}


Thus, in patients with abdominal sepsis caused by pancreatic necrosis, moderate imbalance of cytokine regulation of the immune response is characterized by a prolonged decrease in blood IL-6 with a slight progressive increase in IL-4, which occurs against the background of constant concentration in blood plasma IL-2 and expression on immunocompetent cells of molecules of the main histocompatibility complex HLA-DR + .

Conclusion. In patients with abdominal sepsis, a violation of the mechanisms of cell adhesion and costimulatory-cooperative interaction of immunocompetent cells was observed in the preoperative period, as indicated by the low level of CD11a + and CD162 + expression on them. The decrease in the content of IL-6 in the blood with a slight progressive increase in the level of IL-4 corresponds to a moderate imbalance of cytokine regulation of the immune response.

\section{References:}

1. Petrov, M.S., Yadav, D. Global epidemiology and holistic prevention of pancreatitis // Nat. Rev. Gastroenterol Hepatol. 2019. Vol.16. P. 175-184. https://doi.org/10.1038/s41575-018-0087-5

2. Seike, T., Komura, T., Shimizu, Y. et al. A case of chronic pancreatitis exacerbation associated with pancreatic arteriovenous malformation: a case report and literature review // Clinical journal of gastroenterology. 2019. Vol. 12(2). P.135-141. https://doi.org/10.1007/s12328-018-0901-1

3. Vorobey A.V., Lurie V.N., Vizhinis E.I. Diagnosis and treatment of acute necrotizing pancreatitis: teaching method. manual // BelMAPO. 2013. P.17.

4. Malmstrøm M. L., Hansen M. B., Andersen A. M. et al. Cytokines and organ failure in acute pancreatitis: inflammatory response in acute pancreatitis // Pancreas. 2012. Vol. 41, N 2. P. 271- 277.

5. Dzhyvak, V. H., Klishch, I. M. Peculiarities of the cytokin profile in rat serum under correction of muscle injury with platelet-riched blood plasma // Bulletin of Medical and Biological Research. 2020. Vol. (3). P. 53-58. https://doi.org/10.11603/bmbr.2706$\underline{6290.2020 .3 .11518}$

6. Abramov G., Shakeyev K., Tusupbekova M. et al. Experimental model of pancreonecrosis induced by auto-bile injection // Open Access Macedonian Journal of Medical Sciences. 2020. Vol. 8(A). P. 472-475. https://doi.org/10.3889/oamjms.2020.4979

7. Shah A. P., Mourad M. M., Bramhall S. R. Acute pancreatitis: current perspectives on diagnosis and management // Journal of inflammation research. 2018. Vol. 11. P. 77-85. https://doi.org/10.2147/JIR.S135751 
8. Kryvoruchko I.A.,. Usenko O. Yu., Andreeshchev S.A. Surgical treatment of patients with abdominal sepsis // Clinical Surgery. 2014. № $8 . \quad$ P. 34-38. https://doi.org/10.26779/2522-1396.2020.1-2.24

9. Martin-Loeches I., Timsit J. F., Leone MKerrigan, S. et al. Clinical controversies in abdominal sepsis. Insights for critical care settings // Journal of critical care. 2019. Vol. 53. P. 53-58. https://doi.org/10.1016/j.jcrc.2019.05.023

10. Mazuski J.E., Tessier J.M., May A.K. et al. The surgical infection society revised guidelines on the management of intra-abdominal infection // Surgical infections. 2017. Vol.18 (1). P. 1-76. https://doi.org/10.1089/sur.2016.261

11. Desiateryk, V. I., Shapovaliuk, V. V., Koynskyi, O. V. et al. Immune imbalance in the pathogenesis of abdominal sepsis in destructive pancreatitis // Hospital surgery. Kovalchuk Magazine. 2016. Vol. 1. https://doi.org/10.11603/2414-4533.2016.1.5871

12. Munez E. Microbiology of surgical site infections in abdominal tract surgery patients // Cir. Esp. 2011. Vol. 89 (9). P. 606-612

13. Zhang, J. M. Cytokines, inflammation, and pain. International anesthesiology clinics // An, J. 2007. Vol. 45 (2). P. 27-37. https://doi.org/10.1097/AIA.0b013e318034194e

14. Shimabukuro-Vornhagen A., Gödel P., Subklewe M., et. al. Cytokine release syndrome // Journal for immunotherapy of cancer, 2018. Vol. 6 (1). P. 56. https://doi.org/10.1186/s40425-018-0343-9

15. Feigenbaum D. C., June C. H. Cytokine Storm // The New England Journal of Medicine. 2020. Vol. 383 (23). P. 2255-2273. https://doi.org/10.1056/NEJMra2026131 